\title{
Influence of sociodemographic factors on dementia and depression onset in the elderly
}

Kosana D. Stanetic ${ }^{1}$, Vesna B. Kevic ${ }^{2}$

${ }^{1}$ Primary Health Center Banja Luka

${ }^{2}$ Medical Faculty, University of Banja Luka, Bosnia and Herzegovina

\section{Uticaj sociodemografskih faktora na pojavu demencije i depresije kod starih osoba}

Kosana D. Stanetićl, Vesna B. Kević ${ }^{2}$

${ }^{1}$ Dom zdravlja, Banja Luka,

${ }^{2}$ Medicinski fakultet, Univerzitet u Banja Luci, Bosna i Hercegovina

\section{Abstract}

Introduction: The most common mental disorders in the elderly are depression and dementia.

Objective: Examine the impact of sociodemographic characteristics on the appearance of depression and dementia in elder patients treated in Primary Health Center (PHC), Banja Luka.

Method: The study included 208 patients over 65 years of age, selected by random selection method, registered in 6 family medicine teams at the PHC Banja Luka in the period from March to May 2016. Respondents completed the Sociodemographic Questionnaire, Beck's Depression Inventory, and Folstein Mini-Mental State Examination (MMSE) for dementia assessment. Different statistical procedures were used in the data processing: descriptive analysis in the form of frequencies and percentages, Chi-square test, T-test. The results of the research were statistically analyzed by SPSS 11.5 program.

Results: The study included 208 patients older than 65 , of whom $38.9 \%$ were male. Impaired cognition was found in $7.2 \%$ and moderate depression in $24.5 \%$ of patients. Dementia was statistically significantly $(\mathrm{p}=0.000)$ more present in the eldest respondents $\geq 81$ years, while depression was mostly present in patients aged 76-80. Physically active individuals were significantly less affected by depression $(\mathrm{p}=$ $0.001)$ and dementia $(p=0.000)$. Dementia and depression occurred more frequently in people living alone and people with a low level of education.

Conclusion: A family physician plays an important role in the early detection of depression and dementia in the elderly, the identification of risk factors, prevention, and treatment of these patients.

Keywords: depression, dementia, elderly, sociodemographic characteristics, early detection

\section{Sažetak}

Uvod. Najčešći mentalni poremećaji kod starih osoba su depresija i demencija.

Cilj rada. Ispitati uticaj sociodemografskih karakteristika na pojavu depresije i demencije kod starijih pacijenata koji se leče u Domu zdravlja (DZ), Banja Luka.

Metod. Studija je obuhvatila 208 pacijenata starijih od 65 godina, koji su odabrani metodom slučajnog uzorka, a registrovani su u 6 timova lekara porodične medicine u DZ Banja Luka. Istraživanje je sprovedeno u periodu od marta do maja 2016. Učesnici su odgovorili na Sociodemografski upitnik, Beckovu skalu depresije i Folsteinov Mini-mental test (MMSE) za procenu demencije. Korišćene su različite statističke procedure u obradi podataka: deskriptivna analiza u obliku frekvencija i procenata, $\chi 2$ test, $T$ test. Rezultati istraživanja su statistički analizirani SPSS 11.5 programom.

Rezultati. Istraživanje je obuhvatilo 208 pacijenata starijih od 65 godina, od kojih su 38.9\% bili muškarci. Poremećaj pamćenja nađen je kod 7.2\%, a umerena depresija kod $24.5 \%$ pacijenata. Demencija je bila statitistički znatno $(p=0.000)$ češće prisutna kod pacijenata starijih od 81 godine, dok je depresija uglavnom nađena kod pacijenata starosti 7680 godina. Fizički aktivne osobe su znatno ređe bile pogođene depresijom ( $p=0.001)$ i demencijom $(p=0.000)$. Demencija i depresija su se češće javljale kod ljudi koji žive sami i kod onih sa nižim obrazovanjem.

Zaključak. Porodični lekar ima značajnu ulogu u ranom otkrivanju depresije i demencije kod starih osoba, identifikaciji faktora rizika, prevenciji bolesti i lečenju ovih pacijenata.

Ključne reči. depresija, demencija, starija lica, sociodemografske karakteristike, rano otkrivanje 


\section{Introduction}

The number of old persons is increasing worldwide and is expected to grow from 841 million in 2013 to two billion in $2050^{1,2}$. The most common mental disorders in the elderly are depression and dementia. According to previous studies conducted worldwide, the prevalence of depression in the elderly varies significantly, with estimates found in the literature ranging from $3 \%$ to $35 \%{ }^{3,4}$. Older age includes more frequent health problems: immobility, financial difficulties, stress, alienation, dissatisfaction, retirement, career loss, loss of a spouse, family members or friends, moving out of children, loss of hope, a decrease of needs and motivations for activities that used to be a normal part of life. These are additional "objective" reasons that create a suitable ground for the depressive reaction of elderly persons. ${ }^{5,6}$ Recognized depression can be very successfully treated, and the elderly respond to treatment as well as younger ones ${ }^{7}$.

Dementia is characterized by progressive intellectual decline, which leads to an inability to meet the basic social, moral and work responsibilities of the affected person. The World Health Organization (WHO) defines dementia as a deterioration of memory with possible associated other cognitive deficits: dysphasia, apraxia, agnosia, and difficulty in orientation and/or making everyday decisions. Age is the most significant risk factor for dementia ${ }^{1,2}$. Numerous epidemiological studies have found that in addition to aging, there are a number of other risk factors for dementia, such as brain injury, depression, low mental capacity at an earlier age, or decreased psycho-physical activity in older age ${ }^{8}$. Other risk factors include hypercholesterolemia, hypertension, atherosclerosis, coronary disease, smoking, obesity, and diabetes ${ }^{9}$. According to the results of extensive population studies, the prevalence of dementia ranges from $9-14 \%$ in older persons over 65 and is as high as $30-35 \%$ in persons over $85^{10}$.

There is more and more evidence showing depression may be a risk factor for the development of dementia ${ }^{11}$. A previous history of depression increases the risk of developing Alzheimer's disease and vascular dementia. This association is important even if depression appeared more than ten years before the appearance of dementia. Depression almost doubles the risk of developing dementia. ${ }^{12}$

\section{Objective}

Examine the impact of sociodemographic characteristics on the appearance of depression and dementia in the elderly treated in family medicine outpatient facilities at the Banja Luka Primary Health Center.

\section{Uvod}

Broj starih osoba se povećava širom sveta i očekuje sa da od 841 milion u 2013. dostigne 2 milijarde 2050 $0^{1,2}$. Najčešći mentalni poremećaji kod starih osoba su depresija i demencija. Prema ranijim studijama, rađenim širom sveta, prevalencija depresije kod starih znatno varira, pri čemu se podaci iz literature kreću od 3\% - 35\% $\%^{3,4}$. Starost nosi sa sobom i češće zdravstvene probleme: nepokretnost, finansijske probleme, stres, otuđivanje, nezadovoljstvo, penzionisanje, gubitak karijere, gubitak supružnika, članova porodice ili prijatelja, odlazak dece, gubitak nade, smanjenje potreba i motivacije za aktivnosti koje su bile normalan deo života. Ovo su dodatni objektivni razlozi za nastanak pogodnog tla za depresivno reagovanje kod $\operatorname{starih}^{5,6}$. Prepoznata depresija može se uspešno lečiti, a stariji odgovaraju na lečenje podjednako uspešno kao i mlađi pacijenti ${ }^{7}$.

Demencija se karakteriše progresivnim intelektualnim padom, koji vodi u nemogućnost da se ispune osnovne socijalne, moralne i radne obaveze kod osoba koje su pogođene. Svetska zdravstvena organizacija (SZO) definiše demenciju kao pogoršanje pamćenja sa mogućim drugim povezanim kognitivnim deficitima: disfazija, apraksija, agnozija i poteškoće u orijentaciji i/ili donošenju svakodnevnih odluka. Starost je najznačajniji faktor rizika za demenciju ${ }^{1,2}$. Brojne epidemiološke studije su pokazale da uz starenje postoje i drugi brojni faktori rizika za demenciju kao što su povrede mozga, depresija, raniji nizak mentalni kapacitet ili smanjena psiho-socijalna aktivnost u starijem dobu ${ }^{8}$. Drugi faktori rizika uključuju hiperholesterolemiju, hipertenziju, aterosklerozu, koronarnu bolest, pušenje, gojaznost i dijabetes ${ }^{9}$. Prema rezultatima obimnih populacionih studija prevalencija demencije kreće se od 9\% - 14\% kod starijih od 65 godina, a kreće se i do $30 \%$ - 35\% kod osoba preko 85 godina ${ }^{10}$.

Sve je više dokaza koji ukazuju da depresija može biti faktor rizika za razvoj demencije ${ }^{11}$. Prethodna istorija depresije povećava rizik od razvoja Alchajmerove bolesti i vaskularne demencije. Ova veza je važna čak i kada se depresija javila pre više od 10 godina od pojave demencije. Depresija skoro da udvostručava rizik od razvoja demencije ${ }^{12}$.

\section{Cilj rada}

Cilj istraživanja je bio ispitati uticaj sociodemografskih karakteristika na pojavu depresije i demencije kod starih lica koja se leče u timovima porodične medicine DZ Banja Luka. 


\section{Method}

The study included patients 65 years of age and older who were treated in the Primary Health Center (PHC), Banja Luka. All patients were acquainted with the research objectives and signed their written consent. The Ethics Committee of the Banja Luka Primary Health Center gave its consent for the research. The study was conducted following the Helsinki declaration on medical research and the principles of good scientific practice.

There were 208 participants, selected by random selection method from a registry of patients in six family medicine teams in Primary Health Center (PHC), Banja Luka. Every second patient of 65 years and older was selected from the patient registry regardless of gender. For statistical purposes, all patients were divided into four groups according to age: the first group consisted of patients aged 65 to 70 , the second group patients of 71 to 75 , the third group patients of 76 to 80 and the fourth group 81 years of age and older.

The study was conducted as a prospective study from March 20th, 2016 to May 20th, 2016 using the method of patient surveys and data collection from electronic health records.

We used the following instruments for data collection:

1. A general questionnaire containing socio-demographic data (gender, age, marital and family status, educational degree, physical activity). We measured patients' body weight and height and a Body Mass Index (BMI) was calculated.

2. The presence of depression was determined using Beck's Depression Inventory ${ }^{13,14}$. The Beck Depression Inventory (BDI) is a 21 -item, self-rated scale that evaluates key symptoms of depression including mood, pessimism, sense of failure, self-dissatisfaction, guilt, punishment, self-dislike, self-accusation, suicidal ideas, crying, irritability, social withdrawal, indecisiveness, body image change, work difficulty, insomnia, fatigability, loss of appetite, weight loss, somatic preoccupation, and loss of libido. Individual scale items are scored on a 4-point continuum ( $0=$ least, $3=$ most $)$, with a total summed score range of $0-63$. Higher scores indicate greater depressive severity. The patient's task was to read each question carefully, and then select in each one of them a statement that describes in the best way how the patient felt that week and that day. Each statement was assigned to the appropriate number. By summing, we get a score from which we determine the presence of depression in patients. The standard cutoff scores were as follows: $0-9$ points no depression; $10-18$ points indicate mild depression; 19-29 points indicate moderate depression and score $\geq 30$ indicates severe depression.

3. A short, Folstein Mini-Mental State Examination (MMSE) $^{15}$ is a brief, quantitative measure of cognitive status in adults. It can be used to screen for cognitive impairment, to estimate the severity of cognitive impairment at a given point

\section{Metod}

Studija je uključila pacijente starosti preko 65 godina koji se leče u DZ Banja Luka. Svi pacijenti su upoznati sa ciljem studije i dali su pisani pristanak za učešće u studiji. Etički komitet DZ Banja Luka odobrio je istraživanje. Istraživanje je sprovedeno u skladu sa Helsinškom deklaracijom koja se odnosi na medicinska istraživanja i po principima dobre naučne prakse.

Uključeno je 208 pacijenata, izabranih metodom slučajnog uzorka iz registra pacijenata 6 timova porodične medicine u DZ Banja Luka. Izabran je svaki drugi pacijent starosti preko 65 godina, iz registra pacijenata, bez obzira na pol. Iz statističkih razloga, svi pacijnti su podeljeni u 4 grupe po godinama starosti: prvu grupu činili su pacijenti starosti $65-70$ godina, drugu 71-75, treću 76-80 i četvrtu pacijenti preko 81 godine.

Istraživanje je bilo prospektivno i rađeno je od 20. marta do 20. maja 2016. koristeći metod istraživanja pacijenata i sakupljanja podataka iz elektronskih kartona.

Koristili smo sledeće metode za sakupljanje podataka:

1. Opšti upitnik koji sadrži sociodemografske podatke (pol, starost, bračni i porodični status, stepen obrazovanja, fizička aktivnost). Merili smo pacijentovu visinu i težinu i izračunavali Indeks telesne mase (BMI).

2. Prisustvo depresije određivano je korišćenjem Beckove skale depresije ${ }^{13,14}$. Ova skala ima 21 pitanje, i zasniva se na samo-procenjivanju ključnih simptoma depresije uključujući raspoloženje, pesimizam, osećaj neuspeha, samonezadovoljstvo, krivica, kazna, ne voleti sebe, samooptuživanje, suicidne ideje, plakanje, iritabilnost, socijalno povlačenje, neodlučnost, promena slike o sebi, poteškoće na poslu, nesanica, umor, gubitak apetita, gubitak telesne težine, preokupacija somatskim simptomima i gubitak libida. Odgovori su bodovani sa 4 boda ( 0 - najmanje, 3 - najviše). Ukupan broj bodova je mogao biti od $0-63$. Veći rezultat ukazuje na ozbiljniju depresiju. Pacijentov zadatak je bio da pročita svako pitanje pažljivo i da za svako od njih odabere odgovor koji najbolje opisuje kako se pacijent osećao te nedelje i tog dana. Svaki odgovor je nosio odgovarajući broj bodova. Sabiranjem bodova dobili smo rezultat na osnovu koga smo procenjivali prisustvo depresije kod ovih pacijenata. Standard za rezultate je bio sledeći: 0-9 bodova, nema depresije; 10-18 bodova označava blagu depresiju; 19-29 bodova označava umerenu depresiju, a 30 i više bodova označava ozbiljnu depresiju.

3. Kratka Folsteinova Mini-mental skala (MMSE) ${ }^{15}$ je brz, kvantitativan test kognitivnog statusa kod odraslih. Može se koristiti za skrining kognitivnog oštećenja, za procenu ozbiljnosti kognitivnog oštećenja u datom trenutku, za praćenje kognitivnih promena kod pacijenata koji su već oboleli i da bi se dokumentovao pacijentov odgovor na lečenje. Ovim upitnikom testirali smo pacijentovu orijentaciju, sadašnju 
in time, to follow the course of cognitive changes in an individual over time, and to document an individual's response to treatment. With this questionnaire, we tested patient orientation, current memory, attention and calculation, memory and language. By summing all the individual scores, we got a final score which indicated the level of cognition in our patients. The MMSE has a maximum score of 30 points. The scores are generally grouped as follows: $24-30$ points: normal cognition; $19-23$ points: borderline cognition and $<19$ points impaired cognition.

\section{Statistical processing and data analysis}

We have statistically analyzed the results of the research in SPSS 11.5 program on several levels. Different statistical procedures were used in the data processing: descriptive analysis in the form of frequencies and percentages for sample and response review of each question individually. Differences between individual categories of respondents (age, gender, number of household members, education level, etc.) were analyzed by the Chi-square test on the measuring scales (mental status, depression). A T-test was used to compare the average values of the two groups of respondents. In all applied analytical methods, the significance level was 0.05 and 0.01 .

\section{Results}

The study included 208 patients older than 65 years. Out of this number, 81 were men (38.9\%) and 127 women (61.1\%). The average age of the respondents was 73.7 years. The majority of patients were 65 to 70 years of age - 76 $(36.5 \%)$, and $31(14.9 \%)$ were 81 or older. The majority of the respondents are married - 127 (61.1\%), while $73(35.1 \%)$ are widowed. A small number of them live alone 57 (27.4\%), with spouses $87(41.8 \%)$ and one third resides in more numerous families with three or more members.

Most patients completed secondary school, 84 (40.4\%), there are 15 without school education (7.2\%), while only 12 $(5.8 \%)$ have an academic degree. The largest number of respondents are pensioners - $190(91 \%)$.

More than half of the respondents are physically inactive, $110(52.9 \%)$ i.e. being active for less than an hour daily, $65(31.3 \%)$ are active for one to three hours a day, while 33 patients (15.9\%) are active over three hours per day.

According to the nutritional status, 41 patients (19.7\%) have normal body weight, 96 patients $(46.2 \%)$ are in the overweight group $\left(\mathrm{BMI}=25.0-29.99 \mathrm{~kg} / \mathrm{m}^{2}\right)$, while a third of the patients (71 patients, $34.1 \%$ ) are obese with BMI $\geq$ $30.0 \mathrm{~kg} / \mathrm{m}^{2}$.

Results from the MMSE questionnaire (Folstein MiniMental test) showed that the highest number of respondents had normal cognition - 149 (71.6\%), borderline 44 (21.2\%), and impaired cognition was present in 15 respondents $(7.2 \%)$. memoriju, pažnju, računanje i jezik. Sabiranjem individualnih rezultata doboli smo konačni rezultat koji je pokazao kognitivni nivo naših pacijenata. MMSE ima maksimalni skor od 30 bodova. Rezultati su generalno grupisani na sledeći način: 24-30 bodova, normalno pamćenje; 19-23 boda, granično oštećenje pamćenja i ispod 19 bodova, oštećeno pamćenje.

\section{Statistička obrada i analiza podataka}

Statistički smo analizirali rezultate istraživanja koristeći SPSS 11.5 program na nekoliko nivoa. Različite statističke procedure su korišćene u obradi podataka: deskriptivna analiza u obliku frekvencija i procenata za pregled uzorka i odgovora svakog individualnog pitanja. Razlike između individualnih kategorija učesnika (starost, pol, broj članova domaćinstva, nivo obrazovanja itd) analizirane su $\chi 2$ testom na mernim skalama (mentalni status, depresija). T-test je korišćen za upoređivanje srednjih vrednosti dve grupe učesnika studije. U svim primenjenim analitičkim metodama nivo značajnosti je bio 0.05 i 0.01 .

\section{Rezultati}

Istraživanje je obuhvatilo 208 pacijenata starijih od 65 godina. Od ukupnog broja 81 su bili muškarci (38.9\%), a 127 žene $(61.1 \%)$. Prosečna starost ispitanika je bila 73.7 godina. Većina pacijenata bila je starosti od $65-70$ godina, njih $76(36.5 \%)$, a $31(14.9 \%)$ su bili 81 godinu i stariji. Većina ispitanika je bila u braku 127 (61.1\%), dok je $73(35.1 \%)$ izgubilo bračnog partnera. Manji broj živi sam 57 (27.4\%), sa supružnicima 87 (41.8\%), a jedna trećina živi u višečlanim porodicama (3 i više članova).

Većina ispitanika završila je srednju školu 84 (40.4\%), 15 nema nikakvo obrazovanje (7.2\%), a samo 12 (5.8\%) ima visoko obrazovanje. Najveći broj ispitanika su penzioneri 190 (91\%).

Više od polovine ispitanika su fizički neaktivni 110 (52.9\%), npr aktivni manje od sat vremena dnevno, 65 (31.3\%) su aktivni od 1-3 sata dnevno, dok je 33 (15.9\%) aktivno više od 3 sata dnevno.

Što se tiče uhranjenosti 41 pacijent (19.7\%) ima normalnu telesnu težinu, 96 pacijenata $(46.2 \%)$ su u grupi sa povećanom telesnom težinom $\left(\mathrm{BMI}=25.0-29.99 \mathrm{~kg} / \mathrm{m}^{2}\right)$, dok je trećina pacijenata 71 (34.1\%) gojazna sa $\mathrm{BMI} \geq 30.0$ $\mathrm{kg} / \mathrm{m}^{2}$.

Rezultati MMSE upitnika (Folsteinova Mini-mental skala) pokazuju da je najveći broj ispitanika imao normalnu kogniciju 149 (71.6\%), graničnu $44(21.2 \%)$, a oštećenu 15 $(7.2 \%)$. 
Using Beck's Depression Inventory, it was found that almost half of the patients tested had no elements of depression - $102(49.1 \%)$, mild depression was observed in 55 (26.4\%), and moderate in $51(24.5 \%)$ patients.

In our study, the highest number of patients had normal cognition - 149 (71.6\%), which was mostly observed in the group of the youngest respondents aged 65 to 70 years - 64 (84.2\%). Impaired cognition is mostly prevalent in patients of 81 years of age and older, and a statistically significant difference $(p=0.000)$ between age and dementia is observed, in a way that the respondents of the oldest age have the highest percentage of impaired cognition and the youngest respondents of 65 to 70 years of age have the lowest percentage of impaired cognition (Table 1). Out of all respondents, mild and moderate depression is present in 106 (51.0\%) patients. Age was statistically significantly affected by depression $(p=0.010)$. Moderate depression is mostly expreed in patients over 76 years of age, with the lowest number of patients - 10 $(13.2 \%)$ in the youngest age group 65 to 70 years. The majority of patients with no depression were found in the group of the youngest respondents - 45 (59.2\%) (Table 1).
Uticaj sociodemografskih faktora na pojavu demencije i depresije kod starih osoba Opšta medicina 2020;26(1-2):13-23

Koristeći Beckovu skalu depresije, našli smo da gotovo polovina testiranih pacijenata nije imala elemente depresije 102 (49.1\%), blaga depresija je nađena kod 55 (26.4\%), a umerena kod $51(24.5 \%)$.

U našem istraživanju najveći broj pacijenata je imao normalnu kogniciju 149 (71.6\%), što je najčešće bilo zastupljeno u starosnoj grupi 65 - 70 godina, njih 64 (84.2\%). Oštećenu kogniciju najčešće smo sreli kod pacijenata od 81 godine i starijih i primećena je statistički značajna razlika $(\mathrm{p}=0.000)$ između starosti pacijenta i demencije, u smislu da najstariji ispitanici imaju najveći procenat oštećenja kognicije, Najmlađi pacijenti, 65-70 godina, imaju najmanji procenat oštećenja kognicije (Tabela 1). Od ukupnog broja ispitanika, $106(51.0 \%)$ ima blagu i umerenu depresiju. Starost pacijenata je statistički značajno pogođena depresijom $(\mathrm{p}=0.010)$. Umerena depresija se uglavnom javila kod pacijenata preko 76 godina, a najmanji broj pacijenata sa depresijom $10(13.2 \%)$ je nađen u grupi od 65-70 godina. Većina pacijenata bez depresije nađena je u najmlađoj grupi ispitanika 45 (59.2\%) (Tabela 1).

Table 1. Influence of age on cognitive status and depression onset Tabela 1. Uticaj životnog doba na kognitivni status i pojavu depresije

\begin{tabular}{|c|c|c|c|c|c|c|c|}
\hline & \multicolumn{4}{|c|}{ Age / Godište } & \multirow{2}{*}{$\begin{array}{c}\text { Total/ } \\
\text { Ukupno } \\
\text { N(\%) }\end{array}$} & \multirow[b]{2}{*}{$\chi^{2}$ test } & \multirow[b]{2}{*}{ p } \\
\hline & $\begin{array}{l}65-70 \\
\text { N(\%) } \\
\end{array}$ & $\begin{array}{l}71-75 \\
\mathbf{N}(\%) \\
\end{array}$ & $\begin{array}{l}76-80 \\
\mathrm{~N}(\%) \\
\end{array}$ & $\begin{array}{c}\geq 81 \\
\mathrm{~N}(\%)\end{array}$ & & & \\
\hline \multicolumn{8}{|l|}{ Cognitive status / Kognitivni status } \\
\hline Normal / Normalan & $64(84.2)$ & $43(76.8)$ & $29(64.4)$ & $13(41.9)$ & $149(71.6)$ & \multirow{3}{*}{30.347} & \multirow{3}{*}{0.000} \\
\hline Borderline/ Granični & $10(13.2)$ & $10(17.8)$ & $14(31.2)$ & $10(32.3)$ & $44(21.2)$ & & \\
\hline Impaired / Oštećen & $2(2.6)$ & $3(5.4)$ & $2(4.4)$ & $8(25.8)$ & $15(7.2)$ & & \\
\hline \multicolumn{8}{|l|}{ Depression/ Depresija } \\
\hline No depression / Bez depresije & $45(59.2)$ & $30(53.6)$ & $16(35.6)$ & $11(35.4)$ & $102(49.1)$ & & \\
\hline Mild depression / Blaga depresija & $21(27.6)$ & $14(25.0)$ & $14(31.1)$ & $6(19.4)$ & $55(26.4)$ & 16.745 & 0.010 \\
\hline Moderate depression / Umerena depresija & $10(13.2)$ & $12(21.4)$ & $15(33.3)$ & $14(45.2)$ & $51(24.5)$ & & \\
\hline
\end{tabular}

The results of our study have shown that cognitive status was not significantly affected by gender $(\mathrm{p}=0.183)$. Normal cognition was observed in $149(71.6 \%)$ respondents. Impaired cognition was present in $15(7.2 \%)$ respondents, in 3 males $(3.7 \%)$ and 12 females $(9.4 \%)$. (Table 2$)$.

The results of our study have shown that the gender of the respondents did not significantly affect the occurrence of depression $(p=0.312)$. No depression was observed in $102(49.1 \%)$ patients. Moderate depression was present in 51 (24.5\%) respondents, in 18 males $(22.2 \%)$ and 33 females (26.0\%). (Table 2).
Rezultati našeg istraživanja pokazali su da kognitivni status nije bio značajno pogođen polom $(\mathrm{p}=0.183)$. Normalna kognicija utvrđena je kod 149 ispitanika (71.6\%). Oštećena kognicija bila je prisutna kod 15 (7.2\%) ispitanika, 3 muškarca (3.7\%) i 12 žena (9.4\%) (Tabela 2).

Naši rezultati pokazali su da pol ispitanika nije uticao značajno na pojavu depresije $(\mathrm{p}=0.312)$. Bez depresije su bila $102(49.1 \%)$ pacijenta. Umerena depresija je nađena kod 51 pacijenta $(24.5 \%), 18$ muškaraca $(22.2 \%)$ i 33 žene (26.0\%). (Tabela 2) 
Table 2. Influence of gender on cognitive status and depression onset

Tabela 2. Uticaj pola na kognitivni status i pojavu depresije

\begin{tabular}{|c|c|c|c|c|c|}
\hline & \multicolumn{2}{|c|}{ Gender / Pol } & \multirow{2}{*}{$\begin{array}{c}\text { Total/ Ukupno } \\
\text { N (\%) }\end{array}$} & \multirow{2}{*}{$\chi^{2}$ test } & \multirow{2}{*}{$\mathbf{p}$} \\
\hline & Male N (\%) & Female N (\%) & & & \\
\hline \multicolumn{6}{|l|}{ Cognitive status / Kognitivni status } \\
\hline Normal / Normalan & $63(77.8)$ & $86(67.8)$ & $149(71.6)$ & \multirow{3}{*}{3.398} & \multirow{3}{*}{0.183} \\
\hline Borderline / Granični & $15(18.5)$ & $29(22.8)$ & $44(21.2)$ & & \\
\hline Impaired / Oštećen & $3(3.7)$ & $12(9.4)$ & $15(7.2)$ & & \\
\hline \multicolumn{6}{|l|}{ Depression / Depresija } \\
\hline No depression / Bez depresije & $45(55.6)$ & $57(44.9)$ & $102(49.1)$ & \multirow{3}{*}{2.328} & \multirow{3}{*}{0.312} \\
\hline Mild depression / Blaga depresija & $18(22.2)$ & $37(29.1)$ & $55(26.4)$ & & \\
\hline Moderate depression / Umerena depresija & $18(22.2)$ & $33(26.0)$ & $51(24.5)$ & & \\
\hline
\end{tabular}

The results of the study have shown there was a statistically significant difference between physical activity and cognitive status of the patients $(\mathrm{p}=0.000)$. In the group of 15 (7.2\%) patients with impaired cognition, all 15 patients were physically inactive. As physical activity increases, so does the improvement of mental status (Table 3).

Out of the total of 106 patients $(51.0 \%)$ with depression, physical inactivity was reported in $27(24.5 \%)$ patients with mild depression and $39(35.5 \%)$ patients with moderate depression, which is a total of 66 patients with depression. In patients who are active for more than three hours a day, mild depression occurs in $12(36.4 \%)$ and moderate in only one patient. With the increase of physical activity, the appearance of depression decreases $(p=0.001)$ (Table 3$)$.

The results of our study have shown that the nutrition status did not significantly affect cognitive status $(p=0.849)$ or the onset of depression $(\mathrm{p}=0.687)$.
Rezultati našeg istraživanja pokazali su da postoji statistički značajna razlika između fizičke aktivnosti i kognitivnog statusa kod ispitanika $(\mathrm{p}=0.000)$. $\mathrm{U}$ grupi od 15 (7.2\%) pacijenata sa oštećenim pamćenjem svih 15 pacijenata su bili fizički neaktivni. Sa povećanjem fizičke aktivnosti poboljšava se i menatlni status (Tabela 3 ).

Od 106 pacijenata sa depresijom (51.0\%), fizičku neaktivnost prijavilo je njih 27 (24.5\%) sa blagom depresijom i $39(35.5 \%)$ sa umerenom depresijom, što je ukupno 66 pacijenata sa depresijom. Kod pacijenata koji su aktivni više od 3 sata dnevno blaga depresija zabeležena je kod 12 (36.4\%), a umerena samo kod jednog pacijenta. Sa porastom fizičke aktivnosti smanjuje se pojava depresije $(p=0.001)$ (Tabela 3$)$.

Rezultati naše studije pokazali su da uhranjenost ne utiče značajno na kognitivni status $(p=0.849)$ i nastanak depresije $(p=0.687)$.

Table 3. Influence of physical activity on cognitive status and depression onset Tabela 3. Uticaj fizičke aktivnosti na kognitivni status i pojavu depresije

\begin{tabular}{|c|c|c|c|c|c|c|}
\hline & \multicolumn{3}{|c|}{$\begin{array}{l}\text { Physical activity (hours per week)/ } \\
\text { Fizička aktivnost (sati nedeljno) }\end{array}$} & \multirow{2}{*}{$\begin{array}{c}\text { Total / Ukupno } \\
\text { N(\%) }\end{array}$} & \multirow{2}{*}{$\chi^{2}$ test } & \multirow{2}{*}{$\mathbf{p}$} \\
\hline & $\begin{array}{c}0-7 \\
\mathbf{N}(\%) \\
\end{array}$ & $\begin{array}{c}8-21 \\
N(\%)\end{array}$ & $\begin{array}{c}>22 \\
\mathbf{N}(\%)\end{array}$ & & & \\
\hline \multicolumn{7}{|l|}{ Cognitive status / Kognitivni status } \\
\hline Normal / Normalan & $74(67.3)$ & $45(69.2)$ & $30(90.9)$ & $149(71.6)$ & \multirow{3}{*}{20.752} & \multirow{3}{*}{0.000} \\
\hline Borderline / Graničan & $21(19.1)$ & $20(30.8)$ & $3(9.1)$ & $44(21.2)$ & & \\
\hline Impaired / Oštećen & $15(13.6)$ & $0(0.0)$ & $0(0.0)$ & $15(7.2)$ & & \\
\hline \multicolumn{7}{|l|}{ Depression / Depresija } \\
\hline No depression / Bez depresije & $44(40.0)$ & $38(58.5)$ & $20(60.6)$ & $102(49.1)$ & \multirow{3}{*}{18.479} & \multirow{3}{*}{0.001} \\
\hline Mild depression / Blaga depresija & $27(24.5)$ & $16(24.6)$ & $12(36.4)$ & $55(26.4)$ & & \\
\hline Moderate depression / Umerena depresija & $39(35.5)$ & $11(16.9)$ & $1(3.0)$ & $51(24.5)$ & & \\
\hline
\end{tabular}


A statistically significant difference $(\mathrm{p}=0.022)$ was observed between the number of household members and the cognitive status of patients. Cognitive status is better in patients living in a household with two or more members. Impaired cognition is more present in patients living alone (Table 4).

The results have shown a significant statistical difference $(p=0.001)$ between the number of household members and the appearance of depression in patients. Moderate depression appeares in a larger percentage of patients living alone. Out of the total of $106(51.0 \%)$ patients showingelements of depression, $41(27.1 \%)$ with mild depression live in households with two or more family members, but 24 $(42.1 \%)$ with moderate depression live alone (Table 4$).$
Statistički značajna razlika $(\mathrm{p}=0.022)$ primećena je između broja članova domaćinstva i kognitivnog statusa pacijenata. Kognitivni status je bolji kod pacijenata koji žive u domaćinstvima sa dvoje ili više članova. Oštećeno pamćenje je češće prisutno kod pacijenata koji žive sami (Tabela 4).

Rezultati su pokazali značajnu statističku razliku $(\mathrm{p}=0.001)$ između broja članova domaćinstva i pojave depresije kod pacijenata. Umerena depresija se javlja u većem procentu kod pacijenata koji žive sami. Od ukupnog broja pacijenata $106(51.0 \%)$ koji su imali znake depresije, 41 (27.1\%) sa blagom depresijom živeli su u domaćinstvima sa dva ili više članova domaćinstva, ali 24 (42.1\%) sa umerenom depresijom živeli su sami (Tabela 4).

Table 4. Influence of number of household members on cognitive status and depression onset Tabela 4. Uticaj broja članova porodice na kognitivni status i pojavu depresije

\begin{tabular}{|c|c|c|c|c|c|}
\hline & \multicolumn{2}{|c|}{$\begin{array}{c}\text { Number of household members/ } \\
\text { Broj članova domaćinstva }\end{array}$} & \multirow{2}{*}{$\begin{array}{c}\text { Total / } \\
\text { Ukupno }\end{array}$} & \multirow[b]{2}{*}{$\chi^{2}$ test } & \multirow[b]{2}{*}{$\mathbf{p}$} \\
\hline & $\begin{array}{l}\text { Living alone/ } \\
\text { Žive sami }\end{array}$ & $\begin{array}{c}\text { Two or more members/ } \\
\text { Dva ili više članova } \\
\text { domaćinstva }\end{array}$ & & & \\
\hline \multicolumn{6}{|l|}{ Cognitive status / Kognitivni status } \\
\hline Normal / Normalan & $34(59.6)$ & $115(76.2)$ & $149(71.6)$ & \multirow{3}{*}{7.633} & \multirow{3}{*}{0.022} \\
\hline Borderline / Granični & $15(26.3)$ & $29(19.2)$ & $44(21.2)$ & & \\
\hline Impaired / Oštećen & $8(14.1)$ & $7(4.6)$ & $15(7.2)$ & & \\
\hline \multicolumn{6}{|l|}{ Depression / Depresija } \\
\hline No depression / Bez depresije & $19(33.3)$ & $83(55.0)$ & $102(49.1)$ & \multirow{3}{*}{13.958} & \multirow{3}{*}{0.001} \\
\hline Mild depression / Blaga depresija & $14(24.6)$ & $41(27.1)$ & $55(26.4)$ & & \\
\hline Moderate depression / Umerena depresija & $24(42.1)$ & $27(17.9)$ & $51(24.5)$ & & \\
\hline
\end{tabular}

The study results have shown a statistically significant difference between the level of education and cognitive status $(p=0.000)$. As the level of education increases, the number of patients with impaired and borderline cognition decreases (Table 5).

Patients with college and faculty education showed fewer signs of depression. The lower the education level, the more common depression was. When the educational level increased, depression in patients decreased $(\mathrm{p}=0.018)$ (Table 5)
Naši rezultati su pokazali statistički značajnu razliku između stepena obrazovanja i kognitivnog statusa $(p=0.000)$. Sa rastom stepena obrazovanja smanjuje se broj pacijenata sa graničnim oštećenjem pamćenja ili oštećenim pamćenjem (Tabela 5).

Pacijenti sa višim i visokim obrazovanjem imali su manje znakova depresije. Što je niži novo obrazovanja, češća je depresija. Sa povećanjem obrazovnog nivoa smanjivala se i depresija kod pacijenata $(\mathrm{p}=0.018)$ (Tabela 5). 
Table 5. Influence of degree of education on cognitive status and depression onset

Tabela 5. Uticaj stepena obrazovanja na kognitivni status i pojavu depresije

\begin{tabular}{|c|c|c|c|c|c|c|}
\hline & \multicolumn{3}{|c|}{ Level of education / Stepen obrazovanja } & \multirow[b]{2}{*}{$\begin{array}{c}\text { Total/ } \\
\text { Ukupno } \\
\text { N(\%) }\end{array}$} & \multirow[b]{2}{*}{$\chi^{2}$ test } & \multirow[b]{2}{*}{$\mathbf{p}$} \\
\hline & $\begin{array}{c}\text { Primary } \\
\text { education } \\
\text { and lower/ } \\
\text { Osnovna škola } \\
\text { i niže od toga }\end{array}$ & $\begin{array}{l}\text { Secondary } \\
\text { education/ } \\
\text { Srednja } \\
\text { škola }\end{array}$ & $\begin{array}{l}\text { College and } \\
\text { faculty / } \\
\text { Viša škola i } \\
\text { fakultet }\end{array}$ & & & \\
\hline \multicolumn{7}{|l|}{ Cognitive status / Kognitivni status } \\
\hline Normal / Normalan & $45(53.6)$ & $67(79.8)$ & $37(92.5)$ & $149(71.6)$ & \multirow{3}{*}{26.955} & \multirow{3}{*}{0.000} \\
\hline Borderline / Granični & $28(33.3)$ & $15(17.8)$ & $1(2.5)$ & $44(21.2)$ & & \\
\hline Impaired / Ištećen & $11(13.1)$ & $2(2.4)$ & $2(5.0)$ & $15(7.2)$ & & \\
\hline \multicolumn{7}{|l|}{ Depression / Depresija } \\
\hline No depression / Bez depresije & $31(36.9)$ & $46(54.7)$ & $25(62.5)$ & $102(49.1)$ & & \\
\hline Mild depression / Blaga depresija & $24(28.6)$ & $24(28.6)$ & $7(17.5)$ & $55(26.4)$ & 11.934 & 0.018 \\
\hline Moderate depression / Umerena depresija & $29(34.5)$ & $14(16.7)$ & $8(20.0)$ & $51(24.5)$ & & \\
\hline
\end{tabular}

\section{Discussion}

In our study, the largest number of patients $(71.6 \%)$ has had normal and $7.2 \%$ impaired cognition. Mild depression was registered in $26.4 \%$ of the patients and moderate depression in $24.5 \%$. Urošević et al. ${ }^{16}$ in their study which included 100 patients aged 65 to 84, conducted at the Ćuprija Primary Health Center, in 2010 have shown that the elderly treated in primary health care had a high percentage $(55.0 \%)$ of depression prevalence.

We have also noted statistically significant differences between age and cognitive status of the patients $(p=0.000)$. The oldest patients have had the most impaired cognition. Depression in our patients is also significantly influenced by age $(p=0.010)$. Mild and moderate depression is present in $51.0 \%$ of our patients. Contrary to our results, in the study of Urošević et al. ${ }^{16}$, no correlation between depression and age was found.

A prospective, analytical study conducted in 2012 by Matović et al. ${ }^{17}$ at the Foča Primary Health Center, on 300 patients older than 70 years, found that pre-obesity was registered in $42.3 \%$, and obesity in $20.8 \%$ of patients. Likewise, in our study, more than half of the patients had nutritional problems (pre-obesity and obesity), which is certainly a health problem. However, overweight and obesity have not been found to be risk factors for depression and dementia.

According to observational and epidemiological studies, a Mediterranean diet with a lot of fish, seafood, cereals, vegetables, citrus fruits, and olive oil protects against vascular diseases and is associated with reduced deterioration of cognitive functions ${ }^{18,19}$. In the prevention of vascular cogni-

\section{Diskusija}

U našem istraživanju najveći broj pacijenata imao je normalno (71.6\%), a 7.2\% oštećeno pamćenje. Blaga depresija registrovana je kod $26.4 \%$, a umerena kod $24.5 \%$ pacijenata. Urošević i sar. ${ }^{16}$ u njihovom istraživanju koje je obuhvatilo 100 ljudi starosti od 65 do 84 godine, sprovedenom u Domu zdravlja Ćuprija 2010. pokazali su da starija lica koja se leče na nivou primarne zdravstvene zaštite imaju visoku učestalost depresije (55\%).

Mi smo takođe primetili statistički značajne razlike između starosnog doba i kognitivnog statusa pacijenata $(\mathrm{p}=0.000)$. Najstariji pacijenti imali su naveća oštećenja pamćenja. Na depresiju je kod naših pacijenata takođe značajno uticala starost pacijenata $(\mathrm{p}=0.010)$. Blaga i umerena depresija je prisutna kod $51 \%$ naših pacijenata. Nasuprot našim rezultatima, u istraživanju Uroševića i sar. ${ }^{16}$ nije nađena veza između depresije i starosti pacijenata.

Prospektivna, analitička studija, koju su sproveli Matović i sar. ${ }^{17}$ u Domu zdravlja, Foča, na 300 pacijenata starosti preko 70 godina, našli su predgojaznost u 42.3\%, a gojaznost u $20.8 \%$ ispitanika. I u našoj studiji više od polovine ispitanika imalo je probleme sa ishranom (predgojaznost i gojaznost), što je svakako zdravstveni problem. Međutim, povećana telesna težina i gojaznost nisu bili faktori rizika za depresiju i demenciju.

Prema opservacionim i epidemiološkim studijama, mediteranska dijeta sa dosta ribe, morskih plodova, žitarica, povrća, citrusnog voća i maslinovog ulja, štiti od vaskularnih bolesti i povezana je sa smanjenim pogoršanjem kognitivnih funkcija ${ }^{18,19}$. U prevenciji vaskularnog kognitivnog oštećenja 
tive impairment, it is advised to stop smoking, moderately consume alcohol, control body weight, and practice moderate physical activity.

No correlation was found between gender, cognitive status and depression onset in our study, while results from other studies showed that women were more likely to become ill. In their study, Matović et al. ${ }^{17}$ found that cognitive functions were significantly better in men than in women, as well as those younger than 80 years of age compared to those over 80 years of age. In their study, Urošević et al. ${ }^{16}$ pointed out that out of 100 patients aged 65 to 84 years, 66 were women, of which $40(60.6 \%)$ belonged to the group of patients with depression. Ajduković et al. ${ }^{20}$ conducted testing in two nursing homes for the elderly. Research results have shown that women, elderly and disabled had higher prevalence of depression.

We found a statistically significant correlation between the degree of physical activity and cognitive status of the patients $(p=0.000)$. As physical activity increases, the cognitive status improves. Patients who were physically active two or more hours per day were not in the category with impaired cognition. Depression decreases with increasing physical activity $(p=0.001)$. Ajduković et al. ${ }^{20}$ found in their study significant differences between mobile and immobile patients in all the variables they have examined. Depression was more prevalent in immobile patients. The average results of mobile elderly persons did not indicate the presence of clinically significant depression.

The number of household members also significantly affected the cognitive status of the patients $(p=0.022)$. Cognitive status is better in patients living in a household with two or more members, while impaired cognition is more prevalent in patients living alone.

There was a statistical significance $(p=0.001)$ between depression prevalence and the number of household members, as our results have shown. Moderate depression occurs more frequently in patients living alone. The same results, that persons living alone are at increased risk for depression, were shown in the study conducted by Matović et al. ${ }^{17}$

The cognitive status of patients depends significantly on their educational background $(p=0.000)$. As the level of education increases, the number of patients with impaired and borderline cognition decreases. With an increasing educational level, depression in patients decreases $(p=0.018)$. In their research, Urošević et al. ${ }^{16}$ found that a group of patients with depression had, on average, a lower level of education than a healthy group, which is consistent with our results.

Given the identified risk factors that accelerate the process of decay of mental functions with age (unhealthy lifestyles, cardiometabolic risk factors, psychosocial factors, chronic health conditions), the role of family physicians in the early detection of risk factors is being imposed. Modification of risk factors in developed countries has already led to savetuje se prestanak pušenja, umeren unos alkohola, kontrola telesne težine i umerena fizička aktivnost.

U našem istraživanju nismo našli vezu između pola, kognitivnog statusa i nastanka depresije, dok su rezultati drugih studija pokazali da žene imaju veće šanse da obole. Matović i sar. ${ }^{17}$ su našli da su kognitivne funkcije bile značajno bolje kod muškarca nego kod žena, kao i kod ljudi ispod 80 godina u poređenju sa onima starijim od 80 godina. U studiji Uroševića i sar. ${ }^{16}$ koja je obuhvatila 100 ljudi starosti između 65 i 84 godine, 66 su bile žene i od njih 40 $(60.6 \%)$ su pripale grupi pacijenata sa depresijom. Ajduković i sar. ${ }^{20}$ testirali su stare osobe u dva staračka doma. Rezultati istraživanja su pokazali da žene, stari i osobe sa invaliditetom imaju veću učestalost depresije.

Pronašli smo da su statistički značajnu korelaciju između stepena fizičke aktivnosti i kognitivnog statusa kod pacijenata $(p=0.000)$. Kako se povećava fizička aktivnost, tako se poboljšava kognitivni status. Pacijenti koji su bili aktivni 2 ili više sati dnevno nisu bili u kategoriji onih sa oštećenim pamćenjem. Depresija se smanjivala sa povećanjem fizičke aktivnosti ( $\mathrm{p}=0.001)$. Ajduković i sar. ${ }^{20}$ su u njihovom istraživanju našli značajnu razliku u svim varijablama koje su ispitivali kada su uporedili pokretne i nepokretne pacijente. Depresija je bila mnogo više zastupljena kod nepokretnih pacijenata. Prosečni rezultati pokretnih, starijih osoba nisu ukazivali na prisustvo klinički značajne depresije.

Broj članova domaćinstva takođe je značajno uticao na kognitivni status pacijenata $(\mathrm{p}=0.022)$. Kognitivni status je bolji kod pacijenata koji žive u domaćinstvima sa dva i više članova, dok je oštećeno pamćenje češće kod pacijenata koji žive sami.

Naši rezultati su pokazali da je postojala statistička značajnost $(\mathrm{p}=0.001)$ između učestalosti depresije i broja članova domaćinstva. Umerena depresija češće se javljala kod pacijenata koji žive sami. Isti rezultati, da osobe koje žive same imaju veći rizik od depresije, pokazani su i u studiji Matovića i sar. ${ }^{17}$

Kognitivni status pacijenata značajno je zavisio od njihovog obrazovanja $(\mathrm{p}=0.000)$. Kako se nivo obrazovanja povećavao, tako se broj pacijenata sa oštećenim ili granično oštećenim pamćenjem smanjivao. Sa povećanjem stepena obrazovanja smanjivala se i depresija kod pacijenata $(\mathrm{p}=$ 0.018). U svom istraživanju Uroševića i sar. ${ }^{16}$ našli su da je grupa pacijenata sa depresijom u proseku imala niži nivo obrazovanja nego zdrava grupa, što je u skladu sa našim nalazima.

Budući da su identifikovani faktori rizika koji ubrzavaju proces propadanja mentalnih funkcija (nezdravi životni stilovi, kardiometabolički faktori rizika, psihosocijalni faktori, hronične bolesti), uloga izabranog lekara u identifikaciji ovih faktora je od velikog značaja. Promena faktora rizika u razvijenim zemljama je već dovela do manjeg pada u broju pacijenata sa demencijom ${ }^{21,22}$. U nekoliko velikih studija $a^{23-25}$ 
a slight decline in the number of patients with dementia ${ }^{21,22}$ Several large studies ${ }^{23-25}$ have shown that non-pharmacological measures (adequate nutrition, physical activity, cognitive training, etc.) have a significant effect in reducing Alzheimer's disease. Also, family physicians should pay more attention to patients with a history of depression. In elderly patients suffering from depression, dementia was found in 3\% after one year and $79 \%$ after four to eighteen years ${ }^{26}$.

Promoting healthy lifestyles as early as young and middle age has got a protective effect on suffering from mental illness in older age. The family physician should educate his/ her patients about the need for constant physical activity from youth to very old age; a continuous psychic activity that involves lifelong learning and the acquisition of new knowledge; introduction of the Mediterranean diet; advise to avoid addiction to tobacco, drugs, alcohol, opiates, black coffee or other agents; advise to be active after retirement; to have an optimistic stand in life, to laugh, to be of a cheerful spirit; not to blame others for their own failures; avoid loneliness, develop good communication, get used to stressful situations; do not accept prejudice about aging and old age as illness, powerlessness, and dependence on others; it is necessary to follow the instructions of physicians in the treatment and use of medicines ${ }^{27,28}$.

\section{Conclusion}

The results of our study have indicated that $7.2 \%$ of the patients have had impaired cognition, $26.4 \%$ had mild and $24.5 \%$ moderate depression. Age, physical activity, number of household members, and educational background have had a statistically significant effect on the appearance of dementia and depression in the elderly, while gender and nutritional status were not statistically significant for their occurrence. A family physician plays an important role in the early detection of depression and dementia in older patients, the identification of risk factors for the diseases, prevention, and treatment of these patients. je pokazano da nefarmakološke mere (odgovarajuća ishrana, fizička aktivnost, kognitivni trening itd) imaju značajan uticaj na smanjenje Alchajmerove bolesti. Takođe, porodični lekari treba da obrate veću pažnju na pacijente sa istorijom depresije. Kod starijih pacijenata obolevanje od depresije, demencije nađeno je u 3\% posle jedne godine, a u 79\% posle $4-18$ godina $^{26}$.

Promovisanje zdravih životnih stilova od rane mladosti i srednjeg doba ima protektivni efekat za konstantnom fizičkom aktivnošću tokom čitavog života, kontinuiranoj psihičkoj aktivnosti koja uključuje i doživotno učenje i usvajanje novih znanja, uvođenju mediteranske dijete, izbegavanju duvana, droga, alkohola, opijata, crne kafe i sl, potrebi da budu aktivni nakon penzionisanja, da budu optimisti,da se smeju, da budu vedrog duha, da ne krive druge za svoje neuspehe, izbegavaju samoću, razvijaju dobru komunikaciju, da se navikavaju na stresne situacije, da ne prihvataju predrasude o starenju i starosti kao bolesti, bespomoćnosti, da zavise od drugih, neophodnosti da se prate saveti lekara $u$ lečenju i upotrebi lekova ${ }^{27,28}$.

\section{Zaključak}

Rezultati naše studije pokazuju da 7.2\% ispitanika ima oštećenje pamćenja, $26.4 \%$ ima blagu a $24.5 \%$ umerenu depresiju. Starost, fizička aktivnost, broj članova domaćinstva imaju statistički značajan uticaj na pojavu demencije i depresije kod starijih, dok pol i uhranjenost nisu statistički značajno uticali na njihovu pojavu. Porodični lekar ima važnu ulogu u ranom otkrivanju demencije i depresije kod starijih pacijenata, identifikaciji faktora rizika, prevenciji i lečenju ovih pacijenata. 


\section{Literatura / Reference}

1. World Health Organization. Definition of an older or elderly person. 2013. Available from: http: //www.who.int/healthinfo/ survey/ageingdefnolder/en/ [cited 2019 Oct 12].

2. United Nations. World Population Ageing 2013. New York, 2013. Available from: http:// www. un.org/.../population/.../ageing/ WorldPopulationAgeingReport2013.shtml [cited 2019 Oct 18].

3. Reidel-Heller SG, Busse A, Angermeyer MC. The state of mental health in oldage across the "oldEuropean Union- a systematic review. Acta Psychiatr Scand 2006; 113: 388-401.doi.org/10.1111/ j.1600-0447.2005.00632.x

4. WHO. Depression. 2011. Available from: http: // www.who.int/mental health/ management/depression/definition/en [cited 2019 Oct 28].

5. Lovretić V, Mihaljević-Peleš A. Je li poremećaj kognitivnih funkcija u depresiji put u demenciju. Soc Psihijat. 2013; 41: 109-17.

6. Hall CA, Reynolds-Iii CF. Late-life depression in the primary care settings: challenges, collaborative care, and prevention. Maturitas.2014;79:147-52. doi: 10.1016/j.maturitas.2014.05.026.

7. Almeida OP. Prevention of depression in older age. Maturitas. 2014;79:136-41. doi: 10.1016/j.maturitas.2014.03.005.

8. Qiu C, Johansson G, Zhu F, Kivipelto M, Winblad B. Prevention of cognitive decline in old age - varying effects of interventions in different populations. Ann Transl Med. 2019; 7 (Suppl 3): S142. doi: 10.21037/atm.2019.06.19

9. Winblad B, Amouyel P, Andrieu S, et al. Defeating Alzheimer's disease and other dementias: a priority for European science and society. Lancet Neurol. 2016; 15:45532. doi: 10.1016/S1474-4422(16)00062-4.

10. Stephan BCM, Birdi R, Tang EZH, et al. Secular Trends in Dementia Prevalence and Incidence Worldwide: A Systematic Review. J Alyheimers Dis.2018; 66: 65380. doi: 10.3233/JAD-180375.

11. Geerlings MI, den Heijer T, Koudstaal PJ, Hofman A, Breteler MM. History of depression, depressive symptoms, and medial temporal lobe atrophy and the risk of Alzheimer disease. Neurology. 2008; 70: 1258-64.doi: 10.1212/01. wnl.0000308937.30473.d1.
12. Jorm AF. History of depression as a risk factor for dementia: Aust N Z J Psychiatry 2001; 35: 776-81.DOI:10.1046/j.14401614.2001.00967.x

13. Beck AT, Ward CH, Mendelson M, Mock J, Erbaugh J (June 1961). An inventory for measuring depression. Arch. Gen. Psychiatry. 1961; 4: 561-71.

14. Beck AT, Steer RA, Garbin MG J. Psychometric properties of the Beck Depression Inventory Twenty-five years of evaluation. Clin. Psychol. Rev. 1988; 8: 77-100. https://doi.org/10.1016/02727358(88)90050-5

15. Folstein Mini-Mental State Examination (MMSE). Available from: http:// blog. hawaii.edu/.../folsein-mini-mental-status. doc. [cited 2019 April 12].

16. Urošević J, Davidović M, Odović $\mathrm{G}$, Alexopoulos CHG, Mitrović Lj. Učestalost depresije kod starih osoba. PONS Med J. 2010; 7 : 144-149.

17. Matović J, Pejović V, Račić M. Sveobuhvatna gerijatrijska procjena pacijenata u ambulantama porodične medicine Doma zdravlja Foča. Biomedicinska istraživanja 2013; 4: 13-25. DOI: 10.7251/BII1301013M

18. Alladi S, Hashinski V. World dementia: One approach does not fit all. Neurology. 2018; 91:264-70.doi: 10.1212/ WNL.0000000000005941.

19. Stephan BCM, Birdi R, Tang EYH, et al. Secular Trends in Dementia Prevalence and Incidence Worldwide: A Systematic Review. J Alzheimers Dis. 2018;66:65380. doi: 10.3233/JAD-180375.

20. Ajduković M, Ručević S, Majdenić M. Odnos depresivnosti, zdravlja $i$ funkcionalne sposobnosti korisnika domova za starije i nemoćne osobe. Zagreb. Rev soc polit. 2013; 20: 149-165. doi: 10.3935/rsp.v20i2.1148

21. Wu YT, Beiser AS, Breteler MMB, et al. The changing prevalence and incidence of dementia over time - current evidence. Nat Rev Neur.2017; 13:327-39. doi: 10.1038/ nrneurol.2017.63.

22. Qiu C, Fratiglioni L. Aging without Dementia is Achievable: Current evidence from Epidemiological Research. J Alzheimers Dis. 2018; 62:933-42. doi: 10.3233/JAD-171037
23. Ngandu T, Lehtisalo J, Solomon A, et al. A 2 year multidomain intervention on diet, exercise, cognitive training, and vascular risk monitoring versus control to prevent cognitive decline in at-risk elderly people (FINGER): a randomized controlled trial. Lancet. 2015; 385:2255-63.DOI: 10.1016/ S0140-6736(15)60461-5

24. Moll van Charante EP, Richard E, Eureling LS, et al. Effectiveness of 6-year multidomain vascular care intervention to prevent dementia (preDIVA): a clusterrandomised controlled trial. Lancet. 2016; 388:797-805.doi: 10.1016/S01406736(16)30950-3.

25. Andrieu S, Guyonnet S, Coley N, et al. Effect of Long-term omega 3 polyunsaturated fatty acid supplementation with or without multidomain intervention on cognitive function in elderly adults with memory complaints (MART): a randomized, placebo-controlled trial. Lancet Neurol.2017;16:377-89. doi: 10.1016/ S1474-4422(17)30040-6.

26. Tao P, Yang SN, Tung YC, Yang MC. Development of Alzheimer disease in old major depressive patient based upon their health status: A retrospective study in Taiwan. Medicine (Baltimor).2019; 98(20):e15527. doi: 10.1097/ MD.0000000000015527.

27. Karsemeijer EGA; Aaronson JA, Bossers WJ, et al. Positive effects of combined cognitive an physical exercise training on cognitive function in older adults with mild cognitive impairment or dementia: A meta-analysis. Ageing Res Rev.2017;40:75-83.doi: 10.1016/j. arr.2017.09.003.

28. Li M, Liu L, Song S, et al. Effect of long-term lifestyle intervention on mild cognitive impairment in hyperthensive occupational population in China. Medicine (Baltimore).2018;97:e1975. doi: 10.1097/MD.0000000000011975

Primljen - Received 14.12.2019. Ispravljen - Corrected 08.02.2020. Prihvaćen - Accepted 12.02.2020. 